Emir. J. Agric. Sci. (1993), $5: 13-37$

\title{
Weed Management in Fruit Trees
}

\section{B.E. Abu-Irmaileh}

Faculty of Agriculture, University of Jordan, Amman, Jordan.

\section{ABSTRACT :}

Wecds interfere with fruit trec management and can reduce growth and yield, especially in young trees. On the other hand, weed existence can be useful in terms of protection against soil erosion, improvement of water percolation, serving as hosts for beneficial biological agents, in addition to other virtucs. Hence, weeds should be managed properly in an integrated manner to suit the existing farming systems. Various research papers are reviewed in this article.

Key words : Weed management, Fruit trees, Weed control methods, Herbicides, Orchards.

\section{INTRODUCTION}

Whenever weed management programs are set, special attention should be focused on the apparent weed beneficial values which include : controlling soil erosion, improving water infiltration and soil holding capacity, harboring beneficial biological agents, source of feed, food, fuel, pollen, medicinal and other useful products, source of germplasm and a source of landscape beauty, in addition to the values which have not yet been discovered (18).

On the other hand, weed impact in any agroecosystem emphasizes the negative pressures of weeds 
on crop production, in view of their interference which leads to yield reduction in quality and quantity, interference with agricultural operations (cultivation, irrigation, fertilization, harvest, pruning, thinning and others), lowering soil surface temperature, thus increasing frost danger, harboring pest agents, besides their indirect effects which include : their potential fire hazard when they are dry, potential health hazard to man or his animals, their interference with civil and road works, plus their inferior economic produce for most of the weeds encountered in the field (18).

Weeds compete with young trees and can reduce early growth of the main branches. Trees tend to initiate flowering and subsequent fruit production at a much earlier stage of development than is desirable. Trees become stunted, and their potential future yields become reduced (8). Young peach trees are vulnerable to weed competition (3).

It was estimated that weeds can reduce growth of young trees by about $50 \%$ (24). They compete for water and nutrients. Weeds compete with fruit trees until they are about four years old. As the orchard matures, weed competition becomes less significant $(13,24,25,32)$. Weed control minimizes weed interference and improves tree growth and yield. When it is performed in the tree row, it increases the growth of young apple and cherry trees. Chemical or mechanical weed control increases trunk circumference and total shoot elongation (Table 1). Trees in plots where weed control was performed came into commercial production one year earlier than trees in the unweeded plots (36). 


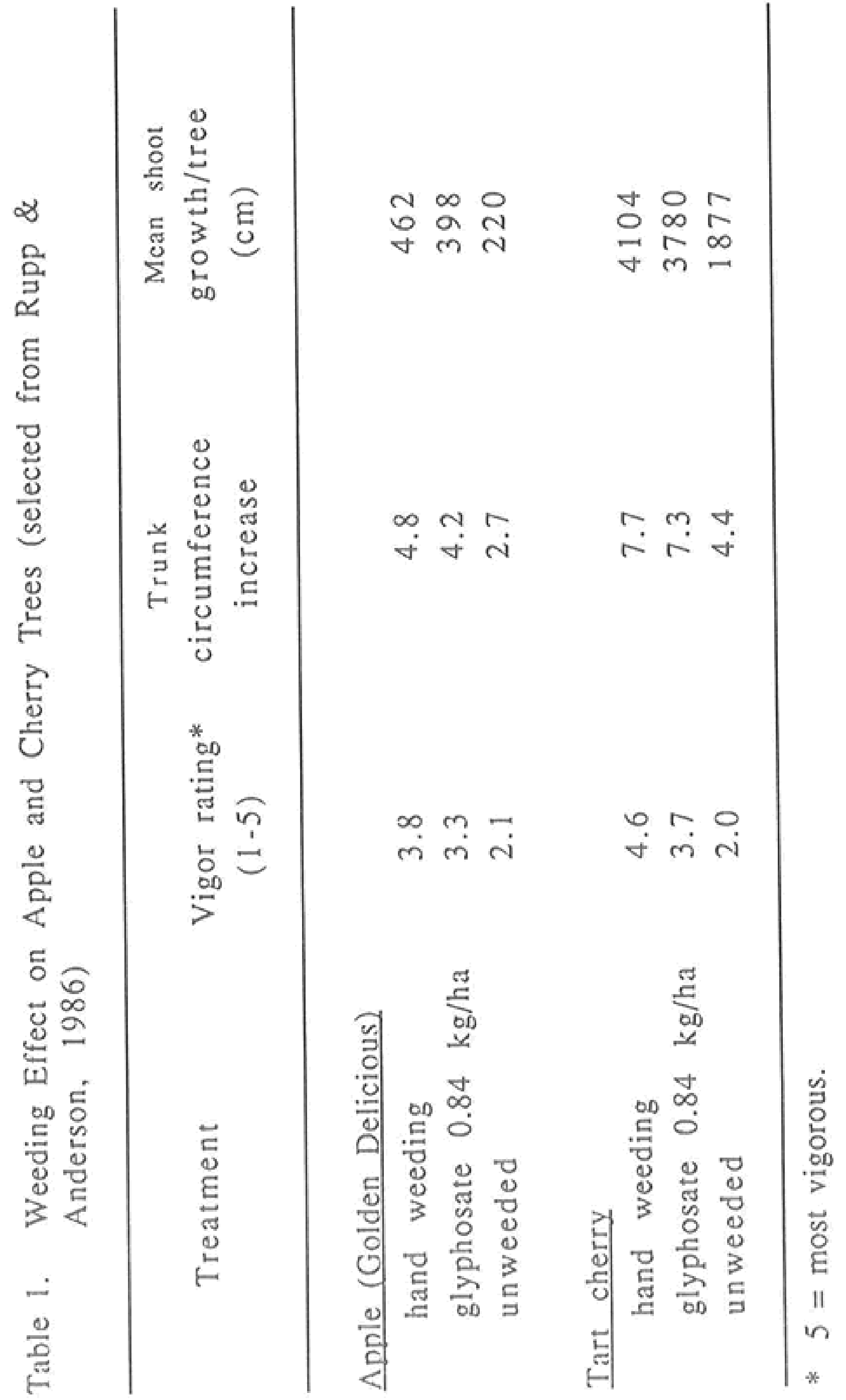


In mature apple orchards, chemical weed control was better than cultivation in increasing tree growth and yield $(15,16)$. Weed management improved yield and quality of Valencia oranges (29).

All cultural operations in the production system affect significantly weed populations, distribution and development of effective methods of weed control. Thus, weed management can be considered as a vegetation management system utilizing all available knowledge and tools to produce crops within the perspective of the socio-economic system on a farm. Different production systems require different or specific weed management methods.

An effective weed control practice on one farm may not suit another farm, or it could be damaging, due to differences in cropping system, soil, cultivar, irrigation and management practices. Planning for weed management should be made in advance, taking into consideration flexibility in order to account for unforeseen events that might be beyond control. An effective weed management program should be economical, fit the farmer capabilities and could be integrated in the production system (39). Weed management should be viewed and decided upon through careful consideration of their negative impact as well as their positive values.

Farmers have been attacking weeds, whether they mean it or not, through a combination of methods within a crop management system; starting with field selection and site-preparation, planting, incorporation of fertilizers, ridging, post planting 
tillage, irrigation, rotation, sanitation, pest control and so on. Various practices can be performed throughout the lifespan of the orchard to aid in weed management. The following points are examples of such practices (39).

1. Proper levelling, grading and contouring are essential practices for planting, and installing the suitable irrigation system so as to :

a. insure uniform water distribution.

b. avoid excessive ponding.

c. check soil erosion potential.

d. consequently, insure better weed management.

e. orchards planted on hillsides, with deepripping down the tree row allows better water infiltration, which provides tree seedlings a chance for faster establishment and better competitive abilities with the natural vegetation. Weed management in slopy orchards should help prevent soil erosion. A strip chemical weed control down the tree rows with mowing the centers is probably most suitable $(18,28,39)$. Planting orchards on terraces or on coutours of hillsides reduces erosion in conjunction with cultivation. Where feasible, combinations of mowing, or sod culture and chemical weed control reduces soil compaction and erosion (20).

2. Variety and rootstocks chosen influence greatly weed management. Much of the herbicide selectivity in orchards is due to their placement, 
and physiological plant tolerance which vary even among different varieties of the same crop $(27,30)$.

Although triazines and substituted ureas are quite toxic to nonbearing young fruit tree seedling, there are differences among species and cultivars (12, 26, 27). Rootstock-scion responses have been shown for almonds, peaches, and plums (26), and peaches and apricots (42). Mission almond is more sensitive to simazine than Nonpareil, and both scions are more sensitive to simazine on Marriana plum than on Lovell or Nemagard rootstock (26). Dwarf apple cultivars are sensitive to diuron than semidwarf or normal growing apples.

3. Frost hazard also influence weed management in the site. Weeds lower soil temperature by several degrees compared to weed-free surface. Clean firm soil surface would contribute to frost protection in grapes, almonds and citrus (23, 39).

4. Plant spacing also influence weed management. Farmers are shifting towards narrower spacing for higher production. Wider spacing allows :

a. intercropping with different crops such as vegetables, or different fruit trees; which in turn reduce weed populations, and thus influence weed management.

b. Planting the middles with annual winter and summer crops, or with semi- 
permanent or permanent sod with notill weed control down the tree row.

Clean no-till is favored in narrow spacing system, relying mainly on chemical weed control.

\section{Weed Control Methods in Orchards}

1. Mechanical methods include soil tillage with various disc types, rototillers, animal plow, mowing, slashing weeds in the middles and hand-hoeing around the tree base.

However, constant cultivation is damaging to soil tilth, causes soil compaction, and results in the formation of a plow sole which retards water infiltration. The feeder roots which grow in the tilled portion of the soil are continually destroyed, and become of no use to the tree (20). Soil erosion is frequently a problem in cultivated orchards. Tillage has also the disadvantage of increasing sometimes disease and insect problems (47). Crop injury, soil compaction, dust production are among the limitations of mechanical methods. Dust produced by tillage operations increased mite problem, and lowered the quality of harvest (7, $19,39)$.

2. Chemical weed control method is generally used in orchards, either alone or in combination with other methods for increasing tree growth and yield $(1,9,29,37,45,48)$. Herbicides proved to be useful and perform better than cultivation in 
many aspects. They could be more economic, faster with higher efficiency weed control compared to mechanical methods. In some soils, they improved water infiltration (14, 19). Certain triazine herbicides were reported to increase plant protein content (37). This was explained by inhibition of denitrification in the soil, consequently, $\mathrm{NO}_{3}-\mathrm{N}$ was increased (31). Less frost injury during bloom was reported in clean no-till orchards (23). However, many setbacks are accompanied with herbicide usage. Herbicide combinations have been shown to reduce shifts favored by monoherbicide regimes (45). Herbicide combinations should be selected carefully. Certain herbicide actions antagonize others when combined (2). The continuous use of diuron and simazine resulted in weed shifts which decreased the efficiency of weed control (38). It also results in building up levels injurious to the trees, as well as to following crops in rotation. In order to lower the concentration of such herbicides in the soil, the following steps could be followed :

a. deep plowing would dilute the amount of the herbicide over a larger portion of the soil.

b. incorporation of activated charcoal at about a rate of 1.5 to $3 \mathrm{kgs}$ for each remaining kilogram of the residual herbicide in the soil. Activated charcoal adsorbs large amounts of the residual herbicide. Daily irrigation for one week, and a waiting period for another week 
followed by deep plowing would help solve the problem.

c. If the site is to be rotated with another crop, residual herbicides should not be applied two years prior to the rotation. The site could be planted to annual irrigated crops for one or two years prior to replanting the orchard. Previous chemical application in sites selected for orchards are also important. Chlorsulfuron is used for weed control in cereals. Chlorsulfuron is persistent and its residues can be harmful to succeeding crops (5). Grapevine vegetative growth was reduced when chlorsulfuron was combined with oryzalin (44).

Low rates of herbicides are applied in soils low in organic matter and clay content, since they may pose serious hazards to certain fruit trees (28). Safety margin is greater in heavy soils in which herbicide rate of application should be increased, even doubled to get efficient weed control.

Herbicide persistence and dissipation from soils vary with the herbicide, its application, climatic and soil factors. Some herbicides are long lasting, and are selected for weed control in orchards $(6,17,21,46)$. 
Herbicide recommendation and method of application is determined by weed species, weed stage and distribution, crop varietal physiological tolerance, type of irrigation, soil type, soil surface conditions, pre-harvest period, duration of weed control required, the bearing or nonbearing condition of the trees, rotation, incompatability of a herbicide with other agrochemicals, and other factors influencing the efficiency of herbicide performance.

Even though herbicides are recommended on the label for certain uses (46), experiments for herbicide performance is always advisable locally. Chemical weed control is based on herbicide selectivity. Some herbicides are highly selective, others are not, and could be made selective by proper placement and application. Selectivity however, is not an absolute character of any herbicide. The only common characteristics for these chemicals is their ability to kill plants. Thus, it is expected that crop injury may result from the mishandling of herbicides. Also, weed control failures could be obtained due to improper applications and misunderstanding of factors affecting herbicide performance. For this reason, herbicides must be adapted to local weed flora and environmental conditions.

Herbicide recommendations arose as a result of exhaustive research work under certain sets of conditions. However, due to 
differences in the complex of factors affecting herbicide performance, weed control results differ from what was expected from a herbicide. Local farmer skills, soil type, soil contents, irrigation regimes, environmental conditions, agrochemicals applied, available equipment, rotations, tree age, cultivars, nontarget site and species and others are among the factors that affect herbicide performance, and they are never identical in various locations. Root distribution of fruit trees in California was largely in the $60-120 \mathrm{~cm}$ depth zone. No tree roots were found in the top $30 \mathrm{~cm}$ (34). In Jordan Valley, feeder roots of citrus trees are shallow and they could be seen near the soil surface under basin irrigation.

Herbicides are used in orchards as blanket application for clean no-till, especially in areas that are normally hit by frost (39); or in 1.5 to $2.5 \mathrm{~m}$ strip down the tree row, leaving the centers to be either tilled, or mowed. Mowing is practiced on contour plantings, under drip, rain or sprinkler irrigations, whereas strip chemical weed control with tilled centers are used in furrow and flood irrigation $(18,28,39)$.

Among the many perennial weeds that dominate orchards in warm regions are :

Cynodon dactylon. Cyperus esculentus. Cyperus rotundus, Convolvulus arvensis, Sorghum halepense, Prosopis farcta. Glycerrhiza glabra. And, among the parasitic weeds that envade citrus, grapes, olives and other fruit 
trees is Cuscuta monogyna. A combination of chemical weed control with tillage and cultural practices should be recruited for better control of such weeds.

Physical methods include mulching and soil solarization. Recent advancement indicated the possible use of soil solarization in many fruit trees for controlling not only weeds but soilborne diseases as well (11). Mulching with hay or black plastic proved to be effective in weed control, conserving moisture, and improving the yield.

Post planting soil solarization was effective for weed and disease control in many orchard situations. Black plastic mulching was better than glyphosate application and grass sod in producing yields during the first two years of grape production. By the third year, glyphosate was equal to black plastic mulching, and both were superior to grass sod (29). Black plastic mulching was suggested as an effective cultural technique in many fruit tree orchards $(4,33,41$, 43). The usefulness of black plastic mulching and soil solarization will depend mostly on the economics as well as their positive and negative impacts on the environment.

For better weed management in orchards, weed control should start as early as preplanting the orchard. At site preparation, the following practices can be carried out (22). 
a. perennial weeds can be controlled by summer plowing, dessicating rhizomes and other propagules, and fall treatment with systemic short residual herbicide such as glyphosate at the preflowering stage. Weeds should be irrigated prior to herbicide application. Stressed weeds do not respond to glyphosate application (46). Any tillage should be delayed for at least one week after this treatment.

b. a preplant standard treatment for newly planted trees and vines, is trifluralin application in almond, apricot, citrus, nectarines, peach, pecan, walnuts, and grapes. Trifluralin should be incorporated in the soil. Planting holes should not be treated (22).

c. Trifluralin can be applied post planting with higher rates in almond, apricot, grape, grapefruit, lemon, nectarine, oranges, peach, plums, prunes, tangeloes, tangerine, and walnut. Napropamide, pendimethalin and/or oryzalin compliment trifluralin activity. Trifluralin is safe because it is placed above the root zone. It is insoluble, and does not leach. Lower rates are applied on light soils. Oryzalin, pendimethalin and napropamide are applied on moist soil, then activated by rain, or sprinkler irrigation during the dormant tree stage, preemergent to weeds. Such treatments should be stopped if buds start to swell. Napropamide should 
not be applied to grapes younger than three years. Oxyfluorfen is a long residual herbicide. It can be applied on newly planted dormant trees. Its application is safe in grapevines older than three years. This herbicide should be applied one month prior to bud swell on moist surface. It can be mixed with the previous herbicides. Oxyfluorfen should not be applied when temperature warms up (22).

Post emergence herbicides for annual and perennial grass control in nonbearing orchards include sethoxydim and fluarzifop-butyl. These herbicides should be combined with surfactants or crop oil. Their application should be stopped one year before harvest. They are not registered yet for wed control in bearing orchards. Paraquat is category one herbicide, requires protective clothing. It can be applied in bearing as well as in nonbearing orchards as directed spray. Glyphosate is registered for weed control in non-bearing orchards. It must be applied as directed spray. This herbicide can cause tree injury if it is drifted to trees especially to leaves or other green tissues $(1,10)$. Glyphosate residues were discovered in fruits (35).

Complete chemical weed control is normally practiced in citrus, and increasingly in stone fruits. This method can be advantageous for maximum frost protection, saving labor, energy, and moisture, and get orchard to mature earlier. But it might be costly since soil surface may crust and seal, reducing water infiltration, 
and increasing the chances of runoff and soil erosion (39).

Plant residues and other plant pruned debris, should be removed prior to herbicide application. Field borders are sites of potential source of weed infestation if left unattended. Weed control can be done mechanically by slashing, burning, mowing, discing or chemically by using proper herbicide applications.

During winter, when weeds are growing, a combination of pre- and post-emergence herbicides can be used. Oxyfluorfen and glyphosate with a proper surfactant is an economic standard application around field borders. Simazine, diuron, amitrole are among the herbicides that can be applied, but they are risky at higher rates in areas adjacent to trees. Low rates are recommended for safety to adjacent trees and for retreatment if required. Herbicide application should be made after heavy rains have passed in order to reduce lateral movement of the herbicides from sudden rains.

Weed growth is favored along irrigation ditches. The weed seeds and other propagules could be distributed all over the field by irrigation water. Weeds should be removed and not allowed to set seeds. Weeds can be controlled by hand hoeing or slashing, and if it is too laborious, residual herbicides can be applied. A standard residual herbicide is diuron or a mix of diuron and simazine at hight rates $(0.5$ to 2 
$\mathrm{kg} / \mathrm{d}$ ) are applied to dry ditches before the irrigation season, then allowed to be moved into the ditch soil, by filling the ditch with water for three days. The ditch must be drained, prior to use for irrigation. Several other herbicides can be applied such as glyphosate, amitrole, atrazine, and paraquat.

\section{General considerations for Weed Management in :}

A. Non bearing orchards

1. Spring clean cultivation, or clean no-till is needed beginning after growth starts.

2. Where cover crops are planted (summer or winter), the crop should be disked in the soil in order to increase organic matter (40).

3. On slopes, weed control is accomplished by :

a. cultivation on the contour, across the slope, in a way to enable water harvesting around the trees, and to prevent soil erosion.

b. chemical weed control can be performed along the tree row. Clean soil surface helps protect trees against frost, in addition to minimizing weed competition and eliminating other indirect effects.

c. shallow strip cultivation in tree row, leaving sod or cover crop or natural vegetation to be mowed periodically. 
4. Weed control can be accomplished by mulching (41). Mulch can either be hay or black plastic. Black plastic mulch was found to increase tree growth by $50-500 \%$ in many cases. Add nitrogen to hasten mulch degredation around the trees, and reduce microorganism competition for $\mathrm{N}$ with trees, in case the mulch used was hay.

\section{B. Bearing orchards}

1. Annual cover crop is suggested in the middles in addition to chemical weed control in the tree row. As the trees get older (3-5 years), shift to permanent sod in fertile soil.

2. Managing cover crop is important so as not to spread in tree rows and compete with the trees.

3. Choose herbicides recommended for bearing orchards.

4. Remove leaves, pruned branches and other plant residues prior to herbicide application.

5. In case of occurring frost, disc plant cover in the soil, pack the soil surface by water well before bloom to enhance heat movement upward from soil on cold nights. 


\section{Future outlook}

Weed management research will never stop. New results can be discovered in specialized journals every day. Many of the herbicides that are effective against weeds are waiting registration in orchard situations.

Besides the discovery of many side-effects of herbicides on human health and environmental pollution, ground water contamination has been reported in areas where herbicides are extensively used. With the new regulations for protecting the environment, restrictions on herbicide usage forced researchers to look for other weed control approaches.

Even though weed resistance to herbicides is not a surmounting issue, weed shifts do occur in situations where mono-herbicide weed management is applied. Herbicide combinations, integration with other weed control measures, genetic engineering for aiding herbicide selectivity, allelopathy are only few examples on current research issues.

Soil solarization for controlling soil pests including weeds, was the subject of the First International Conference on Soil Solarization held in Amman, Jordan in 1990 (11).

\section{Literature cited}

1. Aldrich, J. H. and C.E. Arnold. 1984. Effects of glyphosate on peach tree growth and fruiting. Hortscience 19 : 540 - 542 . 
Emir. J. Agric. Sci. (1993), $5: 13-37$

Weed Management in Fruit Trees

B.E. Abu-Irmaileh

Faculty of Agriculture, University of Jordan, Amman, Jordan.

\section{ABSTRACT :}

Weeds interfere with fruit tree management and can reduce growth and yield, especially in young trees. On the other hand, weed existence can be uscful in terms of protection against soil crosion, improvement of water percolation, serving as hosts for beneficial biological agents, in addition to other virtues. Hence, weeds should be managed properly in an integrated manner to suit the existing farming systems. Various research papers are reviewed in this article.

Key words : Weed management, Fruit trees, Weed control methods, Herbicides, Orchards.

\section{INTRODUCTION}

Whenever weed management programs are set, special attention should be focused on the apparent weed beneficial values which include : controlling soil erosion, improving water infiltration and soil holding capacity, harboring beneficial biological agents, source of feed, food, fuel, pollen, medicinal and other useful products, source of germplasm and a source of landscape beauty, in addition to the values which have not yet been discovered (18).

On the other hand, weed impact in any agroecosystem emphasizes the negative pressures of weeds 
11. Devay, J.E., J.J. Stapleton and C.L. Elmore (editors). 1991. Soil Solarization. FAO plant production and protection paper 109. FAO, Rome.

12. Drovak, J. and J. Stanck. 1968. The responses of woody fruit species to different concentrations of simazine in the soil. Weed Abstracts, 17: 436.

13. Gillbert, F., L. Halm and L. Rate. 1965. The growth of red tart cherry trees with annual applications of simazine and diuron. Weeds 13 : 11-14.

14. Harding, R.B. and T.M. Rayan. 1961. Soil salinity and water distribution under nontilage in a differentially fertilized irrigated citrus orchard. Proc. Soc. Hort. Sci. 77: 155-166.

15. Heeny, H.G., V. Warren and S.U. Khan. 1981. Effects of annual repeat applications of simazine, diuron, terbacil and dichlohenil in a mature apple orchard. Can. J. Plant Sci. 61 : 325-339.

16. Heney, H.G., V. Warren and S.U. Khan. 1981. Effects of a rotation of simazine, terbacil and dichlobenil in a mature apple orchard. Can. J. Plant Sci. 61:407-411.

17. Holly, K. and H.A. Roberts. 1963. Persistance of phytotoxicity residues and triazine herbicides $\mathrm{i}$ soil. Weed Res. 3 : 1-10.

18. IPPC-FAO-USAID. 1980. Instructor's manual for weed management. FAO Training series 12. 
19. Jones, W.W., C.B. Cree and T.W. Embleton. 1961. Some effects of nitrogen sources and cultural practices on water intake by soils in a Washington navel orange orchard and on fruit production, size and quality. Proc. Soc. Hort. Sci. 77 : 146-154.

20. Jordan, L.S. and R.C. Russel. 1981. Weed management improves yield and quality of "Valencia" oranges. Hortscience 16: 785.

21. Kearney, P.C., T.J. Sheets and J.W. Smith. 1964. Volatilization of seven S-triazines. Weeds 12 : 83-87.

22. Kempen, H.M. 1987. Growers weed management guide. Thomson Publications, Fresno, California.

23. Kortleve, C. and H.J. Slotboom. 1967. Weed control in the autumn and night frosts. Weed Abstracts. 17 : 437.

24. Larsen, R.P. and S.K. Ries. 1960. Simazine for controlling weeds in fruit trees and grape planting. Weds 8: 671-677.

25. Lange, A.H. 1970. Wed control methods, losses, and costs due to weeds and benefits of Weed control in deciduous fruit nut crops. Weed Science Society of American FAO Int'l Conf. on Weed Control pp: 143-162. 
26. Lange, .H. and C.L. Elmore. 1967. Rootstockscion-herbicide interrelationships in almond. J. Am. Soc. Hort. Sci. 90 : 56-60.

27. Lange, A.H. and J.C. Crane. 1967. The phytotoxicity of several herbicides to deciduous fruit tree seedlings. J.Am. Soc. Hort. Sci. 90 : 4755 .

28. Lange, A.H., J.C. Crane, B.B. Fischer, K.O. Roberts and C.L. Elmore. 1969. Preemergence weed control in young diciduous fruit trees. J. Amer. Soc. Hort. Sci. 94 : 57 - 60.

29. Lord, W.J. and E. Vlach. 1973. Responses of peach trees to herbicides, mulch, mowing and cultivation. Weed Sci. 21 : 227-229.

30. Marriage, P.B. and S.U. Khan. 1978. Differential varietal tolerance of peach seedlings to glyphosate. Weed Sci. 26 : 374-378.

31. McElhannon, W.S., H.A. Mulls and B. Bush. 1984. Simazine and atrazine - suppression of denitrification. Hortsci. 19 : 218-219.

32. Mellenhin, W.M., G. Crabtree and F.D. Raนgh. 1966. Effects of herbicides and weed competition on growth of orchard trees. Proc. Am. Soc. Hort. Sci. 88 : $121-126$.

33. Neilsen, G.H. and E.J. Hogne. 1985. Effect of orchard soil management on the growth and leaf concentration of young dwarf Red Delivious apple trees. Can. J. Soil. Sci. 65 : 309 - 315. 
34. Proebsting, E.L. 1943. Root distribution of some desiduous fruit trees in a California orchard. Proc. Amer. Soc. Hort. Sci $43: 1-4$.

35. Putnam, A.R. 1976. Fate of glyphosate in deciduous fruit trees. Weed Sci. 24 : 425-430.

36. Rupp, L.A. and J.L. Anderson. 1986. Growth and fruiting responses of young apple and tart cherry trees to weed control. Hortscience 20 : $727-729$.

37. Ries, S.K., R.P. Larsen, and A.L. Kenworthy. 1963. The apparent influence of simazine on nitrogen nutrition of peach and apple trees. Weeds 11 : $270-273$.

38. Schubert, O.E. 1972. Plant cover changes following herbicide applications in orchards. Weed Sci. $20: 124-127$.

39. Sieckert, E.E., C.L. Almore and A.H. Lange. 1985. Horticultural crops. Ch. 12 In. California weed conference. 1985. Principles of weed control in California. pp. 327-343. Thomson publications, Fresno.

40. Stevenson, D.S. 1975. Responses of diamond grapes to irrigation frequency with and without cover crop. Hortscience 10:82-84.

41. Stevenson, D.S., G.H. Neilsen and A. Cornelsen. 1986. The effect of woren plastic mulch, herbicides, grass sod, and nitrogen on "Foch" 
grapes under irrigation. Hortscience 21 : 439 441.

42. Tweedy, J.A. and S.K. Pies. 1966.Fruit tree tolerance to two triazines. Weeds $14: 268-269$.

43. Volosky, Y.S. 1983. Use of white and black polyethylene as a mulch in "Vineyard" of cv. "Torontel" (Vitis vinifera L.) trained or espaliers. Vitis $22: 241$ - 246.

44. Warmund, M.R. and W.K. Patterson. 1986. Vegetative and fruiting responses of grapes to chlorsulfuron and oryzaline. Hortsci. 21 : 250252.

45. Welker, W.V. 1984. The effects of oryzalin alone and in combination with diuron and simazine on young peach trees. Hortscience. 19 : 824-826.

46. Weed Sc. Soc. Am. 1989. Herbicide handbook of the WSSK Champaign. ILL.

47. arwood, J.D. 1969. Tillage increases plant diseases. Calif. Agric. 23 : 4-6.

48. Young, R.S. and W.V. Welker. 1981. Oryzalin alone and in combination for the culture of fruit trees. Proc. NE. Weed Sci. Soc. 35 : 138 - 143. 


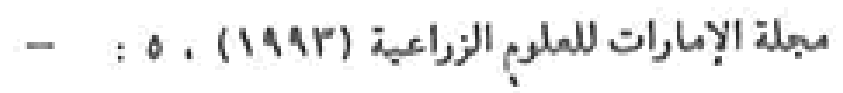

إدارة الأعشاب الضارة في بساتين الفاكهة

ركان أبورميلة

كلية الزراعة - الجامعة الأردنية - علان - الأردن

:

يؤدي وجـود الأعشاب إلى تقليل نمو وإنتاج أثشجـار الفاكهة ، وذلك عن طريق منافستها



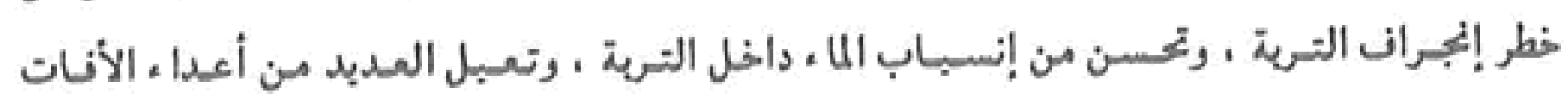
الطببعبة بالإضافة إلى نوائد أخرى . وعلى هذا ، نإنه يبجب مكافهة الأعشاب بطريقة متكاملة لتلاثم الواتع الزراعي الموجود . ولتد تم مراجعة العديد من الأبحاث التي تتعلق في هذا المجال . 